๑О. М. Кетова, А. М. Громова, Т. Ю. Ляховська, Л. А. Нестеренко, В. В. Талаш Полтавсъкий державний медичний університет

\title{
СУЧАСНІ АСПЕКТИ ДІАГНОСТИКИ ТА РЕАБІЛІТАЦІї СИНДРОМУ ХРОНІЧНОГО ТАЗОВОГО БОЛЮ У ЖІНОК ПРИ ВАРИКОЗНОМУ РОЗШИРЕННІ ВЕН ОРГАНІВ РЕПРОДУКТИВНОЇ СИСТЕМИ
}

Мета дослідження - вивчити прояви варикозного розширення вен органів малого таза у жінок репродуктивного віку провести оцінку ефективності гірудотерапії при реабілітації гінекологічних хворих із даною патологією після оперативного лікування.

Матеріали та методи. Обстежено 27 пацієнток із варикозним розширенням вен малого таза після хірургічного лікування з приводу гінекологічної патології. Проводили гінекологічне дослідження та загальноклінічні обстеження, необхідні для проведення оперативного втручання, оцінили загальне самопочуття за допомогою авторської анкети, здійснили трансвагінальне ультразвукове дослідження з доплерометрією артерій і вен матки. Одержані результати оброблено за статистичними методами.

Результати дослідження та їх обговорення. При УзД було виявлено варикозно розширені вени, що визначались як покручені, анехогенні структури по ребру матки. У середньому діаметр маткових вен до лікування в обстежених жінок був $(0,93 \pm 0,02)$ см праворуч і $(0,92 \pm 0,02)$ см зліва, діаметр внутрішньої клубової вени - $(1,16 \pm 0,02)$ см праворуч і $(1,15 \pm 0,02)$ см зліва, діаметр правої яєчникової вени становив $(0,48 \pm 0,02)$ см, лівої яєчникової вени - $(0,49 \pm 0,02)$ см. У результаті проведеного лікування відмічалось поліпшення венозного відтоку та зменшення застою в органах малого таза, що підтверджено зменшенням діаметра судин малого таза: внутрішньої клубової вени праворуч у 1,5, ліворуч - в 1,4 раза; яєчникової вени - у 1,8 та в 1,9 раза відповідно; маткових вен - у 1,7 раза з обох боків. Запропонована методика лікування варикозного розширення вен малого таза із застосуванням медичних п'явок інтравагінально сприяло зменшенню больових відчуттів у 4 рази, загальне самопочуття і настрій покращувались у 3 рази, соціальна адаптація та лібідо - у 2,5 раза.

Висновок. Запропонована методика реабілітації при варикозному разширенні вен малого таза після оперативного лікування є досить ефективною, що доведено результатами клінічних та інструментальних методів дослідження, а також дозволяє досягти ліквідації больового синдрому та значно підвищити якість життя хворих і їх соціальну активність.

Ключові слова: варикозне розширення вен; органи репродуктивної системи; інтравагінальна гірудотерапія.

СОВРЕМЕННЫЕ АСПЕКТЫ ДИАГНОСТИКИ И РЕАБИЛИТАЦИИ СИНДРОМА ХРОНИЧЕСКОЙ ТАЗОВОЙ БОЛИ У ЖЕНЩИН ПРИ ВАРИКОЗНОМ РАСШИРЕНИИ ВЕН ОРГАНОВ РЕПРОДУКТИВНОЙ СИСТЕМЫ

Цель исследования - изучить проявления варикозного расширения вен органов малого таза у женщин репродуктивного возраста и провести оценку эффективности гирудотерапии при реабилитации гинекологических больных с данной патологией после оперативного лечения.

Материалы и методы. Обследовано 27 пациенток с варикозным расширением вен малого таза после хирургического лечения по поводу гинекологической патологии. Проводили гинекологическое исследование и общеклинические обследования, необходимые для проведения оперативного вмешательства, оценили общее самочувствие с помощью авторской анкеты, провели трансвагинальное ультразвуковое исследование с допплерометрией артерий и вен матки. Полученные результаты обработаны статистическими методами.

Результаты исследования и их обсуждение. При УзИ были выявлены варикозно расширенные вены, которые определялись как извитые, анэхогенные структуры по ребру матки. В среднем диаметр маточных вен до лечения равнялся $(0,93 \pm 0,02)$ см справа и $(0,92 \pm 0,02)$ см слева, диаметр внутренней подвздошной вены - $(1,16 \pm 0,02)$ см справа и $(1,15 \pm 0,02)$ см слева, диаметр правой яичниковой вены составлял $(0,48 \pm 0,02) \mathrm{cm}$, левой яичниковой вены - $(0,49 \pm 0,02)$ см. В результате проведенного лечения отмечалось улучшение венозного оттока и уменьшение застоя в органах малого таза, что подтверждено уменьшением диаметра сосудов малого таза: внутренней подвздошной вены справа в 1,5, слева - в 1,4 раза; яичниковой вены - в 1,8 и в 1,9 раза соответственно; маточных вен - в 1,7 раза с обеих сторон. Предложенная методика лечения варикозного расширения вен малого таза с применением медицинских пиявок интравагинально способствовала уменьшению болевых ощущений в 4 раза, общее самочувствие и настроение улучшались в 3 раза, социальная адаптация и либидо - в 2,5 раза.

Вывод. Предложенная методика реабилитации при варикозном расширении вен малого таза после оперативного лечения является достаточно эсрфективной, что доказано результатами клинических и инструментальных методов исследования, а также позволяет достичь ликвидации болевого синдрома и значительно повысить качество жизни больных и их социальную активность.

Ключевые слова: варикозное расширение вен; органы репродуктивной системы; интравагинальная гирудотерапия.

MODERN ASPECTS OF DIAGNOSIS AND REHABILITATION OF CHRONIC PELVIC PAIN SYNDROME IN WOMEN WITH VARICOSE OF THE REPRODUCTIVE SYSTEM

The aim of the study - to learn the manifestations of varicose veins of the pelvic organs in women of reproductive age and to evaluate the effectiveness of hirudotherapy in the rehabilitation of gynecological patients with this pathology after surgery.

Materials and Methods. After surgical treatment 27 patients with varicose veins of the pelvis were examined for gynecological pathology. Gynecological examination and general clinical examinations required for surgery, assessment of "General well-being" 
using the author's questionnaire, transvaginal ultrasound with Doppler arteries and veins of the uterus were conducted. The obtained results were processed by statistical methods.

Results and Discussion. Ultrasound revealed varicose veins, which were defined as twisted, anechogenic structures along the rib of the uterus. The average diameter of the uterine veins before treatment in the studied women was $(0.93 \pm 0.02) \mathrm{cm}$ on the right and $(0.92 \pm 0.02)$ on the left, the diameter of the internal iliac vein $-(1.16 \pm 0.02) \mathrm{cm}$ on the right and $(1.15 \pm 0.02) \mathrm{cm}$, the diameter of the right ovarian vein was $(0.48 \pm 0.02) \mathrm{cm}$, the left ovarian vein $-(0.49 \pm 0.02) \mathrm{cm}$. As a result of the treatment there was an improvement in venous outflow and reduction of stagnation in the pelvic organs, which was confirmed by diameter of the vessels of the pelvis: internal iliac vein on the right 1.5, left - 1.4 times; ovarian vein 1.8 and 1.9 times, respectively; uterine veins 1.7 times on both sides. The proposed method of treatment of varicose veins of the pelvis with the use of medical leeches intravaginally helped to reduce pain by 4 times, general well-being and mood improved by 3 times, social adaptation and libido - by 2.5 times.

Conclusion. The proposed method of rehabilitation for varicose veins of the pelvis after surgery is quite effective as evidenced by the results of clinical and instrumental research methods and also allows to eliminate pain and significantly improve the quality of life of patients and their social activity.

Key words: varicose veins; organs of reproductive system; intravaginal hirudotherapy.

ВСТУП. Варикозне розширення вен органів репродуктивної системи - це патологія, що буває переважно у жінок репродуктивного віку [1, 2]. На даний час для визначення поняття варикозної хвороби вен малого таза у вітчизняній та іноземній літературах використовують ряд різноманітних, однак за змістом однозначних термінів: тазовий варикоз, тазова варикозна недостатність, тазова венозна патологія, варикозна хвороба вен малого таза, варикозне розширення вен малого таза, синдром венозного повнокров'я малого таза [3-6]. Зважаючи на дослідження та публікації останніх років з даної тематики, єдиного погляду щодо диференційного підходу до діагностики та лікування даної патології немає [7-9]. Зрозуміло, що існує прямий зв'язок між порушенням венозного відтоку від органів малого таза та гінекологічними, урологічними захворюваннями, а також іншими нозологічними чинниками як генітальної, так і екстрагенітальної ссрери $[10,11]$. Відомо, що основним проявом варикозу органів малого таза є хронічний тазовий біль, який, у свою чергу, супроводжує більшість гінекологічних процесів. Утруднює верифрікацію діагнозу різноманітність клінічних проявів синдрому тазового венозного повнокров'я, що можуть «маскуватися» під запалення органів черевної порожнини, малого таза, заочеревинного простору, захворювання суглобів, хребта, неврологічні проблеми тощо [12-14]. Тому при лікуванні основного захворювання неможливо не зважати на той фракт, що порушення гемодинаміки органів малого таза, з одного боку, може посилювати перебіг основного захворювання, а з іншого - давати хибну симптоматичну картину [15]. Також необхідно пам'ятати, що гормональна терапія, без якої, на жаль, неможливо обійтися при лікуванні та реабілітації гінекологічної патології, посилює венозний стаз. Тому ми вважаємо, що при діагностиці захворювань жіночої репродуктивної системи необхідно оцінювати і зважати на стан гемодинаміки органів малого таза [16-18]. На нашу думку, в багатьох випадках це дозволить уникнути тривалого необґрунтованого призначення різних препаратів і зменшить медикаментозне навантаження на організм [19].

МЕТА ДОСЛІДЖЕННЯ - вивчити прояви варикозного розширення вен органів малого таза у жінок репродуктивного віку і провести оцінку ефективності гірудотерапії при реабілітації гінекологічних хворих з даною патологією після оперативного лікування.

МАТЕРІАЛИ І МЕТОДИ. У дослідження було включено 27 пацієнток з варикозним розширенням вен малого таза після хірургічного лікування із приводу гінекологічної патології. Для досягнення поставленої мети на першому етапі ми провели клініко-статистичний аналіз документації, анамнезу, соціального статусу, клінічних проявів захворювання. Також оцінили загальне самопочуття за допомогою авторської анкети [19]. Жінкам пропонували охарактеризувати та оцінити свій загальний стан та самопочуття від 0 до 5 балів: больові відчуття на даний час (0 - біль відсутній, 5 - занадто сильний), самопочуття (0 - гарне самопочуття, 5 - депресивний стан), настрій (0 - гарний емоційний стан, 5 - сумний нудьгуючий стан), соціальну адаптацію (0 - спокійно виконую повсякденні справи, 5 - нічого не можу робити), стан лібідо (0 - позитивна енергія сексуального потягу, 5 - відсутність сексуального потягу). Проводили об'єктивне гінекологічне дослідження та спектр загальноклінічних обстежень, необхідних для проведення оперативного втручання. Обов'язково усім пацієнткам виконували трансвагінальне ультразвукове дослідження з доплерометрією артерій і вен матки та яєчників. При необхідності проводили і оцінювали інші методи обстеження (МРТ, колоноскопію) для виключення супутньої патології. Лапароскопію виконували за стандартною методикою. В період реабілітації після лікувально-діагностичної лапароскопії з метою корекції порушення кровообігу при ВРВРС проводили гірудотерапію. Після проведеного оперативного втручання, через 1 тиждень після чергової менструації, виконували інтравагінальну гірудотерапію для нормалізації венозного тонусу, регіонарної гемодинаміки в органах малого таза та з протизапальною метою. За методикою, яку ми запропонували, використовували медичні п'явки: інтравагінально (на бокові склепіння піхви), через день, № 10 [20] (рис. 1).

Одержані результати оброблені статистичними методами 3 використанням програмного забезпечення Microsoft Excel, параметричних і непараметричних методів оцінки. Достовірність відмінностей отриманих величин визначали за допомогою t-критерію Стьюдента.

РЕЗУЛЬТАТИ ДОСЛІДЖЕННЯ ТА ЇХ ОБГОВОРЕНня. Ми провели обстеження 27 жінок у віці 26-42 років із варикозним розширенням вен малого таза. Провідним симптомом до проведення лікування у 23 (85,2\%) жінок була пельвалгія. Так, 18 (66,7 \%) пацієнток відзначали відчуття тяжкості й болю в малому тазі, що виникає при тривалих статичних навантаженнях, фрізичній роботі, під час статевого акту, передменструальний біль був у 15 


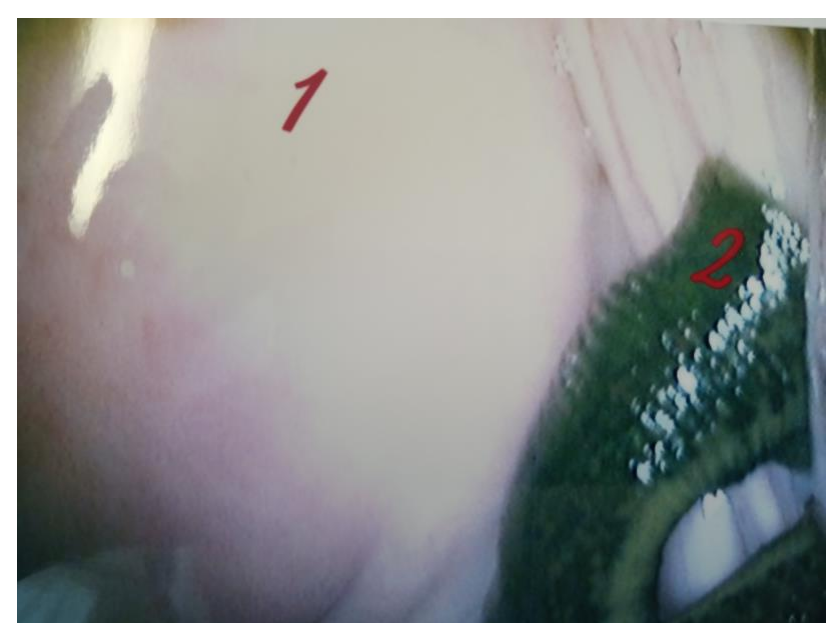

Рис. 1. Інтравагінальна гірудотерапія (1 - шийка матки; 2 - медична п'явка).

(55,5 \%) обстежених, диспареурія - у 8 (29,6 \%), біль і підвищену чутливість в ділянці промежини і вульви спостерігали в 11 (40,7 \%). При аналізі даних анкетування 3'ясовано, що вираження болю у середньому склало $(4,11 \pm 0,1)$ бала, що мало негативний вплив на загальне самопочуття $-4,26 \pm 0,09$, настрій $-3,37 \pm 0,08$, соціальну адаптацію - 4,13 $\pm 0,1$, а також лібідо жінок - $(4,33 \pm 0,12)$ бала. При аналізі даних анкети виявлено паралельні зв'язки між усіма її показниками при високому коефріцієнт кореляції $(p<0,001)$.

При УЗД було виявлено варикозно розширені вени, що визначались як покручені, анехогенні структури по ребру матки. Варикозне розширення внутрішніх клубових вен виявлялось як анехогенне утворення 3 нечіткими контурами з внутрішніх стінок таза. Результати доплерографрічних досліджень виявляли зниження пікової систолічної швидкості в маткових, яєчникових і внутрішніх клубових венах. У режимі кольорового доплерівського картування зображення варикозу вен таза виглядали як кольорові плями неправильної фоорми - «симптом озер» (рис. 2).

У середньому діаметр маткових вен до лікування в обстежених жінок був $(0,93 \pm 0,02)$ см праворуч і $(0,92 \pm 0,02)$ cм зліва, діаметр внутрішньої клубової вени - $(1,16 \pm 0,02) \mathrm{cm}$ праворуч і $(1,15 \pm 0,02)$ см, діаметр правої яєчникової вени становив $(0,48 \pm 0,02)$ см, лівої яєчникової вени $(0,49 \pm 0,02)$ см. У якості критерію варикозу та виявлення рефлюксу проводили пробу Вальсави. Ми виявили, що отвір вен яєчників збільшувався в середньому більше ніж на 0,5 см і був $(1,18 \pm 0,03)$ см справа і $(1,18 \pm 0,03) \mathrm{cm}$ зліва $(p<0,005)$.

При проведенні лапароскопії було виявлено варикозно розширені вени таза в ділянці яєчників за ходом круглої і широкої зв'язки матки у вигляді синюшних конгломератів із витонченими і напруженими стінками (рис. 3).

Під час лапароскопії було виконано такі об'єми оперативних втручань: однобічну тубектомію у 9 (33,3 \%) жінок, двобічну тубектомію - у 5 (18,5 \%) жінок, резекцію яєчників - у 7 (25,9 \%) жінок, однобічну аднексектомію -у 2 (7,4 \%), видалення вогнищ ендометріозу - в 4 (14,8 \%). Роз'єднання злук було виконано у 59,3 \% пацієнток.

Методика реабілітації хворих із варикозним розширенням вен органів малого таза, яку ми запропонували, сприяла зменшенню больових відчуттів і, як наслідок, поліпшенню психологічного та емоційного стану пацієнток. На наступній діаграмі представлено дані щодо позитивних змін показників анкети «Загальне самопо-

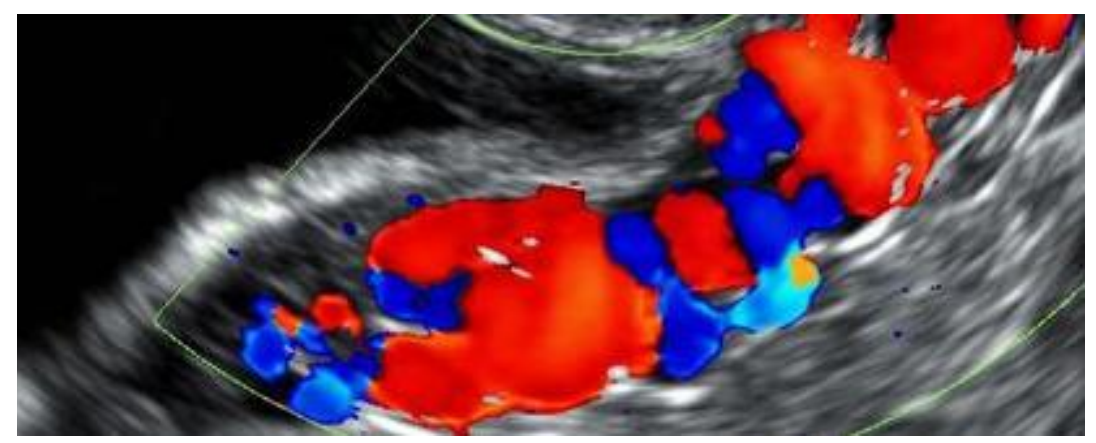

Рис. 2. Доплерометричне дослідження внутрішніх клубових вен.

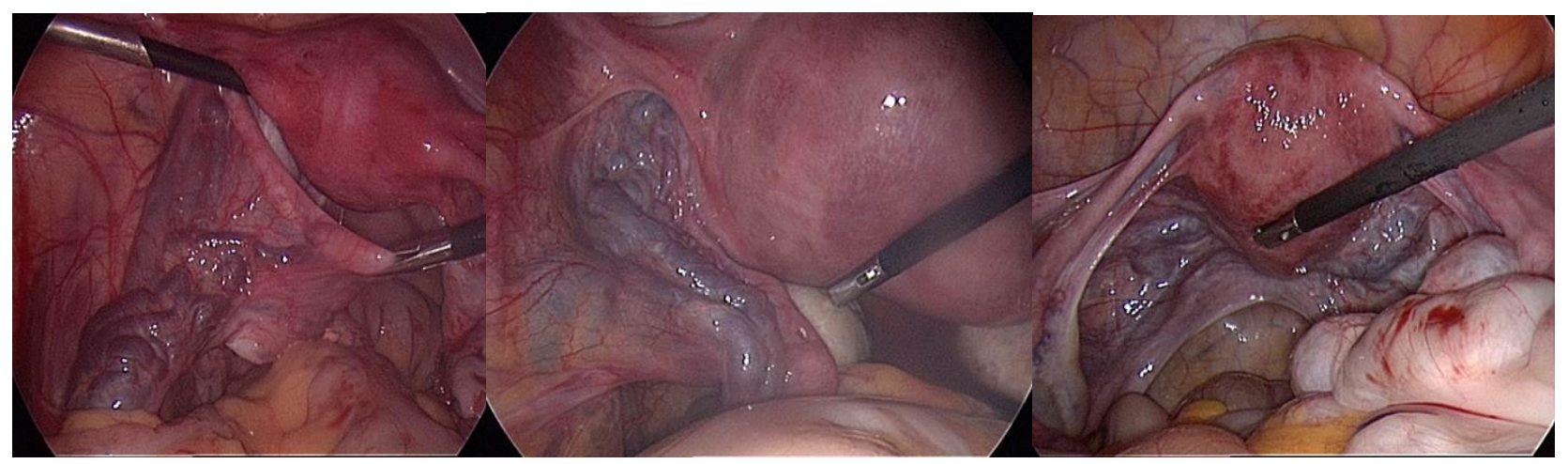

Рис. 3. Варикозне розширення вен органів малого таза жінок. 
чуття» до лікування та через місяць після проведеного комплексного лікування. Як видно з представлених даних (рис. 4), больові відчуття зменшились у 4 рази, загальне самопочуття і настрій поліпшились у 3 рази, соціальна адаптація та лібідо - у 2,5 раза.

Після проведення курсу реабілітаційних заходів із застосуванням інтравагінальної гірудотерапії повторно проводили ультразвукове обстеження 3 доплероме- трією для оцінки діаметра судин та кровотоку в них. Діаметр маткових вен склав справа $(0,54 \pm 0,12)$ см і зліва $(0,53 \pm 0,06) \mathrm{cm}$, діаметр внутрішньої клубової вени - $(0,79 \pm 0,11)$ см і $(8 \pm 0,02)$ см відповідно, діаметр правої яєчникової вени становив $(0,26 \pm 0,01) \mathrm{cm}$, лівої яєчникової вени - $(0,25 \pm 0,02)$ см (рис. 5), що свідчить про значний позитивний вплив запропонованої методики на кровообіг органів малого таза.

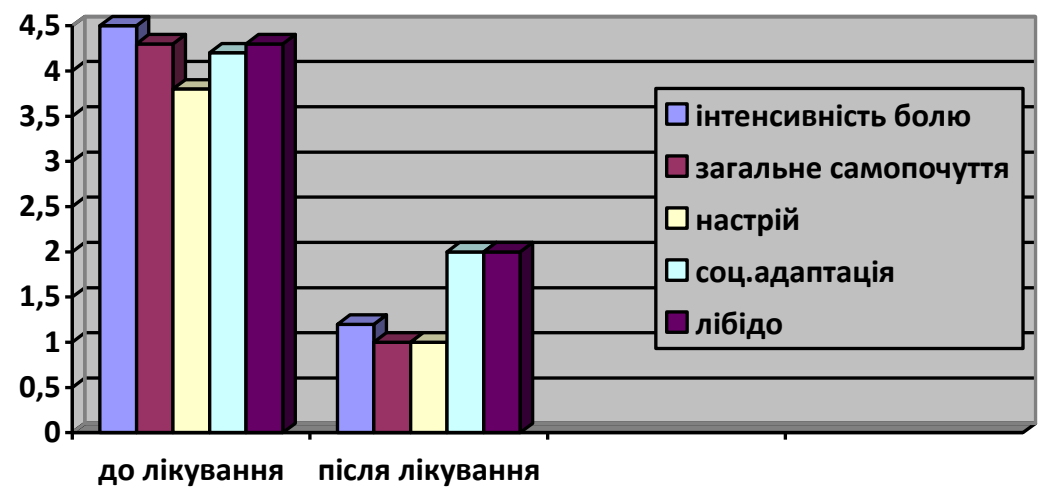

Рис. 4. Зміни загального самопочуття пацієнток до і після лікування.

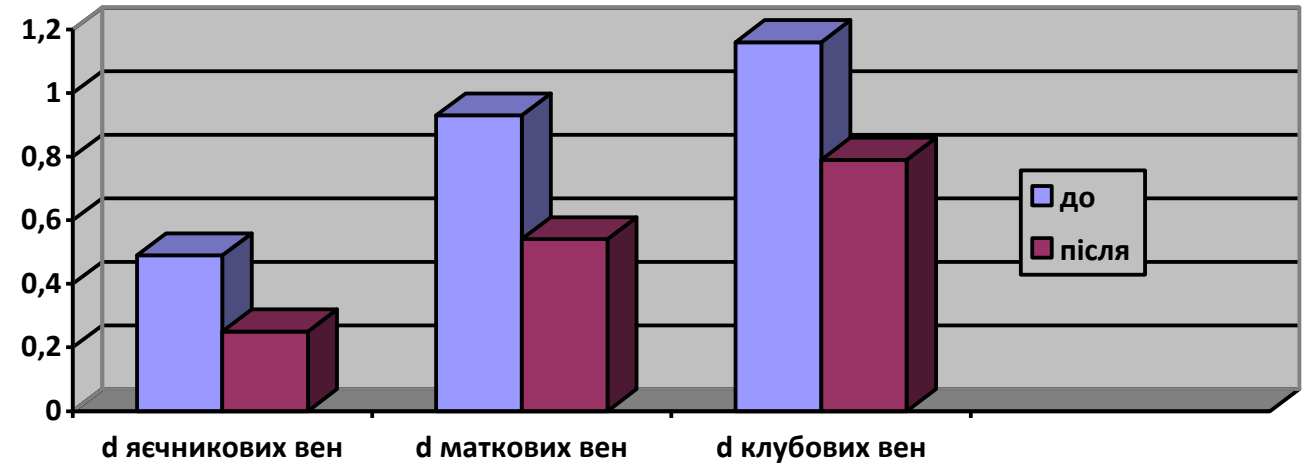

Рис. 5. Зміни діаметра судин до і після лікування.

ВИСновкИ. 1. Запропонована методика лікування варикозного розширення вен малого таза із застосуванням медичних п'явок інтравагінально сприяла зменшенню больових відчуттів у 4 рази, загальне самопочуття і настрій поліпшились у 3 рази, соціальна адаптація та лібідо - у 2,5 раза.

2. У результаті проведеного лікування відмітили покращення венозного відтоку та зменшення застою в органах малого таза, що підтверджено зменшенням діаметра судин малого таза: внутрішньої клубової вени праворуч у 1,5, ліворуч - в 1,4 раза; яєчникової вени - у 1,8 та в 1,9 раза відповідно; маткових вен - у 1,7 раза з обох боків.

3. Запропонована методика реабілітації при варикозному разширенні вен малого таза після оперативного лікування є досить есрективною, що довели результати клінічних та інструментальних методів дослідження, а також дозволяє досягти ліквідації больового синдрому та значно підвищити якість життя хворих і їх соціальну активність.

ПЕРСПЕКТИВИ ПОДАЛЬШИХ ДОСЛІДЖЕНЬ. ДЛЯ нормалізації венозного тонусу, поліпшення кровотоку в малому тазі, для зниження інтенсивності застійного больового синдрому можна використовувати інтравагінальну гірудотерапію як альтернативний високоефективний неінвазивний метод при різній гінекологічній патології. Причому ми вважаємо, що даний метод може бути застосований як ізольовано, так і в комплексі з іншими методами лікування.

\section{СПИСОК ЛІТЕРАТУРИ}

1. Pelvic congestion syndrome: diagnosis and treatment / E. A. Ignacio, R. Dua, S. Sarin [et al.] // Semin. Intervent. Radiol. - 2008. - Vol. 25 (94). - P. 361-368.
2. Мозес В. Г. Варикозное расширение вен малого таза у женщин / В. Г. Мозес // Новости медицины и фрармации. 2005. - № 18 (178). - С. 17. 
3. Пирогова В. І. Варикозна хвороба вен малого таза і синдром хронічного тазового болю - діагностично-лікувальні аспекти / В.І.Пирогова, С.О.Шурпяк, М. Й. Малачинська // Здоровье женщины. - 2014. - № 4. - С. 30-34.

4. Cheong Y. Chronic pelvic pain: aetiology and therapy / Y. Cheong, S. William // Best Pract. Res. Clin. Obstet. Gynaecol. - 2006. - Vol. 20 (5). - P. 695-711.

5. Dykhuizen R. F. The ovarian vein syndrome / R. F. Dykhuizen, J. A. Roberts // Surg. Gynecol. Obstet. 1970. - Vol. 130 (3). - P. 443-442.

6. Ляховський В. І. Застосування малоінвазивних операцій у лікуванні варикозної хвороби нижніх кінцівок / В. І. Ляховський, А. Л. Боркунов, Д. Г. Дем'янюк [та ін.] // Світ медицини та біології. - 2012. - № 4, т. 8. - С. 35-37.

7. Артымук Н. В. Туманность малого таза. Тазовая веноконгестия как одна из ведущих причин хронической тазовой боли / Н. В. Артымук, О. Д. Руджнева // Status Praesens. - 2015. - Vol. 4 (27). - P. 42-49.

8. Kies D. D. Pelvic congestion syndrome: a review of current diagnostic and minimally invasive treatment modalities / D. D. Kies, H. S. Kim // Phlebol. - 2012. - Vol. 27 (Suppl. 1). - P. 52-57.

9. Вивчення впливу віку та індексу коморбідності на ризик тромботичних ускладнень у хворих на рак ендометрія на доопераційному етапі / Б. Д. Кривокульський, І. В. Жулкевич, Д. Б. Кривокульський, Л. В. Шкробот // Вісник наукових досліджень. - 2018. - № 2. - С. 150-154.

10. Noninvasive diagnostic tools for pelvic congestion syndrome: a systematic review / M. P. Steenbeek, C. J. M. van der Vleuten, L. J. Schultze Kool, T. E. Nieboer // Acta Obstet. Gynecol. Scand. - 2018. - Vol. 97 (7). P. 776-786.

11. Жулкевич І. В. Персоналізація в онкології: індивідуальний підхід до профілактики тромбоемболічних ускладнень при пангістеректомії / І. В. Жулкевич, Б. Д. Кривокульський // Вісник соціальної гігієни та організації охорони здоров'я України. - 2018. - № 4 (78). - С. 11-18.

\section{REFERENCES}

1. Ignacio, E.A., Dua, R., Sarin, S., Harper, A.S., Yim, D., Mathur, V., \& Venbrux, A.C. (2008). Pelvic congestion syndrome: diagnosis and treatment. Semin. Intervent. Radiol., 25 (4), 361-368. DOI: 10.1055/s-0028-1102998.

2. Mozes, V.G. (2005). Varikoznoye rasshireniye ven malogo taza u zhenshchin [Varicose veins of the small pelvis in women]. Novosti meditsiny i farmatsii - Medicine and Pharmacy News, 18 (178), 17 [in Russian].

3. Pyrohova, V.I., Shurpiak, S.O., \& Malachynska, M.Y. (2014). Varykozna khvoroba ven maloho taza i syndrom khronichnoho tazovoho boliu - diahnostychno-likuvalni aspekty [Varicose disease of veins of the small pelvis and chronic pelvic pain syndrome - medical and diagnostic aspects]. Zdorovye zhenshchiny - Woman's Health, 4, 30-34 [in Ukrainian].

4. Cheong, Y., \& William, S. (2006). Chronic pelvic pain: aetiology and therapy. Best Pract. Res. Clin. Obstet. Gynaecol., 20 (5), 695-711. DOI: 10.1016/j.bpobgyn.2006.04.004.

5. Dykhuizen, R.F., \& Roberts, J.A. (1970). The ovarian vein syndrome. Surg. Gynecol. Obstet., 130 (3), 443-452.

6. Lyakhovskyi, V.I., Borkunov, A.L., Demyanyuk, D.G., Sapun, L.V., Lyakhovska, T.U., \& Kravziv, M.I. (2012). Zastosuvannia maloinvazyvnykh operatsii u likuvanni varykoznoi
12. Imaging of venous compression syndromes / E. J. Zucker, S. Ganguli, B. B. Ghoshhajra [et al.] // Cardiovasc. Diagn. Ther. - 2016. - Vol. 6 (6). - P. 519-532.

13. Особливості перебігу післяопераційного періоду у жінок з лейоміомою матки після емболізації маткових артерій / О. В. Литвиненко, А. М. Громова, Л. А. Нестеренко [та ін.] // Світ медицини та біології. - 2019. - № 3 (69). - С. 105-108.

14. Safety, efficacy, and prognostic factors in endovascular treatment of pelvic congestion syndrome / F. Nasser, R. N. Cavalcante, B. B. Affonso [et al.] // Int. J. Gynecol. Obstet. - 2014. - Vol. 125 (1). - P. 65-68.

15. Ліхачов В. К. Застосування препаратів Прутняка звичайного у лікуванні передменструального синдрому / В. К. Ліхачов, Л. М. Добровольська, Т. Ю. Ляховська // Зб. наук. праць Асоціації акушерів-гінекологів України. - К. : «Поліграф плюс», 2013. - 424 с.

16. Громова А. М. Роль ультразвукових параметрів при виборі репродуктивно-пластичних операцій при лейоміомах матки / А. М. Громова, О. Л. Громова, О. М. Кетова // Вісник проблем біології і медицини. - 2014. - Вип. 3, т. 2 (111). С. 260-262.

17. Место эхографрии в диагностике причин синдрома тазовых болей / А. Е. Волков, Н. В. Рымашевский, А. Ф. Михельсон [и др.] // Ультразвуковая диагностика в акушерстве, гинекологии и педиатрии. - 2000. № 2. - С. 133-135.

18. Кривокульський Б. Д. Ризикадаптовані підходи до профрілактики тромботичних ускладнень при гістеректомії / Б. Д. Кривокульський, І. В. Жулкевич // Шпитальна хірургія. Журнал імені Л. Я. Ковальчука. - 2018. - № 2. - С. 78-83.

19. Зятіна О. М. Анкета "Загальне самопочуття" (Свідоцтво про реєстрацію авторського права № 16302 від 13.04.2006) для об'єктивізації оцінювання нервово-психічного стану пацієнток в умовах комплексного лікування.

20. Громова А. М. Гірудотерапія в комплексному лікуванні запальних захворювань придатків матки / А. М. Громова, О. М. Зятіна // Репродуктивное здоровье женщины. - 2006. - № 2 (1 ч.). - C. 76-79.

khvoroby nyzhnikh kintsivok [Minimally invasive interventions for lower limb varicosity]. Svit medytsyny ta biolohii - World of Medicine and Biology, 8, 4, 35-37 [in Ukrainian].

7. Artyimuk, N.V., \& Rudzhneva, O.D. (2015). Tumannost malogo taza. Tazovaya venokongestiya kak odna iz veduschih prichin hronicheskoy tazovoy boli [The small pelvis. Pelvic congestion as one of the leading causes of chronic pelvic pain. Status Praesens, 4 (27), 42-49 [in Russian].

8. Kies, D.D., \& Kim, H.S. (2012). Pelvic congestion syndrome: a review of current diagnostic and minimally invasive treatment modalities. Phlebol., 27 (Suppl. 1), 52-57. DOI: 10.1258/phleb.2012.012s27.

9. Kryvokulskyi, B.D., Zhulkevych, I.V., Kryvokulskyi, D.B., \& Shkrobot, L.V. (2018). Vyvchennia vplyvu viku ta indeksu komorbidnosti na ryzyk trombotychnykh uskladnen u khvorykh na rak endometriia na dooperatsiinomu etapi [Studying the influence of age and comorbidity index on the thrombotic complications risk in patients with endometrial cancer at preoperative stage]. Visnyk naukovykh doslidzhen - Bulletin of Scientific Research, 2, 150-154. DOI: https://doi.org/10.11603/2415-8798.2018.2.9212 [in Ukrainian].

10. Steenbeek, M.P., van der Vleuten, C.J.M., Schultze Kool, 
L.J., \& Nieboer, T.E. (2018). Noninvasive diagnostic tools for pelvic congestion syndrome: a systematic review. Acta Obstet. Gynecol. Scand., 97 (7), 776-786. DOI: 10.1111/aogs.13311.

11. Zhulkevych, I.V., \& Kryvokulskyi, B.D. (2018). Personalizatsiia v onkolohii: indyvidualnyi pidkhid do profilaktyky tromboembolichnykh uskladnen pry panhisterektomi [Personalization in oncology: individual approach to the prevention of thromboembolic complications during hysterectomy]. Visnyk sotsialnoi hihiieny ta orhanizatsii okhorony zdorovia Ukrainy Bulletin of Social Hygiene and Health Protection Organization of Ukraine, 4, 11-18. DOI: https://doi.org/10.11603/16812786.2018.4.9875 [in Ukrainian].

12. Zucker, E.J., Ganguli, S., Ghoshhajra, B.B., Gupta, R., \& Prabhakar, A.M. (2016). Imaging of venous compression syndromes. Cardiovasc. Diagn. Ther., 6 (6), 519-532. DOI: 10.21037/cdt.2016.11.19.

13. Lytvynenko, O.V., Hromova, A.M., Nesterenko, L.A., Martynenko, V.B., \& Lyakhovska, T.Yu. (2019). Osoblyvosti perebihu pisliaoperatsiinoho periodu u zhinok z leiomiomoiu matky pislia embolizatsii matkovykh arterii [Features of the postoperative period in women with uterine leiomyoma after uterine artery embolization]. Svit medytsyny ta biolohii - World of Medicine and Biology, 3 (69), 105-108. DOI 10.26724/20798334-2019-3-69-105-108 [in Ukrainian].

14. Nasser, F., Cavalcante, R.N., Affonso, B.B., Messina, M.L., Carnevale, F.C., \& de Gregorio, M.A. (2014). Safety, efficacy, and prognostic factors in endovascular treatment of pelvic congestion syndrome. Int. J. Gynecol. Obstet., 125 (1), 65-68. DOI: 10.1016/j.ijgo.2013.10.008

15. Likhachov, V.K., Dobrovolska, L.M., \& Liakhovska, T.Yu. (2013). Zastosuvannia preparativ Prutniaka zvychainoho u likuvanni peredmenstrualnoho syndromu [The use of drugs syndrome of Vitex agnus-castus $L$. in the treatment of premenstrual syndrome Vitex agnus-castus L]. Zbirnyk naukovykh prats Asotsiatsii akusheriv-hinekolohiv Ukrainy - Collection of scientific works of the Association of Obste- tricians and Gynecologists of Ukraine. Kyiv: Polihraf plius [in Ukrainian].

16. Hromova, A.M., Hromova, O.L., \& Ketova, O.M. (2014). Rol ultrazvukovykh parametriv pry vybori reproduktyvnoplastychnykh operatsii pry leiomiomakh matky [The role of ultrasound parameters in the choice of reproductive plastic surgery for uterine leiomyomas]. Visnyk problem biolohii i medytsyny - Bulletin of Problems of Biology and Medicine, 2 (3), 260-262 [in Ukrainian].

17. Volkov, A.Ye., Rymashevskiy, N.V., Mikhelson, A.F., Okorokov, A.A., Karnushin, Ye.I., \& Kazaryan, M.S. (2000). Mesto ehografii $v$ diagnostike prichin sindroma tazovyh boley [The place of echography in the diagnosis of the causes of pelvic pain syndrome]. Ultrazvukovaya diagnostika vakusherstve, ginekologii i pediatrii - Ultrasound Diagnostics in Obstetrics, Gynecology and Pediatrics, 2, 133-135 [in Russian].

18. Kryvokulsky, B.D., \& Zhulkevich, I.V. (2018). Ryzykadaptovani pidkhody do profilaktyky trombotychnykh uskladnen pry histerektomii [Risk adapted approaches to prophylaxis of thrombotic complications at gisterectomy]. Shpytalna khirurhiia. Zhurnal imeni L.Ya. Kovalchuka Hospital Surgery. Journal Named by L.Ya. Kovalchuk, 2, 7883. DOI: https://doi.org/10.11603/2414-4533.2018.2.9228 [in Ukrainian].

19. Ziatina, O.M. (2006). Anketa "Zahalne samopochuttia" (Svidotstvo pro reiestratsiiu avtorskoho prava № 16302 vid 13.04.2006) dlia obiektyvizatsii otsiniuvannia nervovopsykhichnoho stanu patsiientok $v$ umovakh kompleksnoho likuvannia [Questionnaire: "General well-being" for objectivity of assessment of neuropsychological condition of patients in the conditions of complex treatment]. [in Ukrainian].

20. Hromova, A.M., \& Zyatina, O.M. (2006). Hirudoterapiia $\checkmark$ kompleksnomu likuvanni zapalnykh zakhvoriuvan prydatkiv matky [Hirudotherapy in the complex treatment of inflammatory diseases of the uterine appendages]. Reproduktyvnoe zdorovye zhenshchyny - Reproductive Health of Women, 2 (Part 1), 7679 [in Ukrainian].

Отримано 06.04.21

Прийнято до друку 07.05.21

Електронна адреса для листування: akushgynec@ukr.net 